\title{
Political Relationship Marketing: An Examination of Internal Relationship Management in
} Ghanaian Political Parties

\author{
Ibrahim Sayibu Nnindini \& Kobby Mensah \\ University of Ghana, Legon, Accra, Ghana \\ nnindini@yahoo.com,kobbymensah@ug.edu.gh
}

\begin{abstract}
In recent times political parties appear to be focusing narrowly on winning elections to the detriment of effective management of their intra-party relationships. The neglect of managing relationships is having a negative effect on parties, hence this study. The study looked at the practice of political relationship marketing in the two leading parties in Ghana, focusing on micro-interactions at the constituency level. Twenty-four party executives were drawn from eight constituencies for interview. Thematic analysis was carried out to identify relationship marketing practices in the parties. The findings demonstrate the presence of some political relationship marketing antecedents. A fully-fledged political relationship marketing practice is however absent.
\end{abstract}

Keywords: Political relationship marketing, Political marketing, internal party management, Communication, Ghana.

\section{Introduction}

This study is situated in Political Relationship Marketing (PRM), instigated by the internal wrangling that has been rocking the political parties in Ghana in recent years despite claims of political marketing practices (Hinson \& Tweneboah-Koduah, 2010; Mensah, 2017). In our view, the wrangling in the parties is a result of obsessive fixation on winning elections to the detriment of the management of internal relationships (Lees-Marshment, 2004), which is least explored both in practice and in the theory of political management in Ghana. It is now an established knowledge globally that politics is designed and promoted on marketing insight (Brown \& Coates, 1996; Henneberg, 2004; Lees-Marshment, 2001; Mensah, 2017; Scammell, 1995; 1999), resulting in political marketing as academic and practice discipline. Since its emergence, political parties and candidates have utilized the political marketing concept in a number of ways (Lees-Marshment, 2019). According to Kotler and Keller (2012), one of the factors that accounted for the success of Barrack Obama in the 2008 United States elections was a welldesigned and effectively executed marketing program.

They argue that the effective use of marketing is not by chance, but an output of meticulous hard work using state-of-the-art tools and techniques. It is however noted that Obama's campaign did not only deploy marketing in its 'managerial' sense where a good product, for example, was designed and distributed using voter insight but also built effective relationships for fundraising (Nickerson \& Rogers, 2014). We see this development as a change in the role of political marketing, that is from "the science of influencing mass behavior in competitive situations" (Mauser, 1983, p. 5) to a new approach that seeks to establish, maintain and enhance long term political relationships at a profit for society, so that the objectives of individual political actors and organizations involved are met" (Henneberg, 2002, p. 103). This shift is necessary because the political marketing literature over the years has been heavily focused on the communication function of marketing (see (Baines \& Egan, 2001; Les-Marshment, 2009; Lilleker \& Jackson, 2013; Scammell, 1995; Wring, 1997); others tend to focus on the strategy dimension, (examples include, Bowler \& Farrell, 1992; Lees-Marshment, 2001; 2004; Newman, 1994; 1999; 0’Shaughnessy, 1990; O’Shaughnessy \& Henneberg, 2002).

The relational approach to marketing has been under-explored in the political marketing literature (Henneberg \& O'Shaughnessy, 2009), despite its potential benefits. Aside from the neglect of the political relationship marketing dimension, there are also very limited political marketing studies conducted at the local level (Reeves, 2009). We choose political relationship marketing as the conceptual framework for this study because we believe that alongside political marketing communication and strategy, there ought to be empirical data that broaden the appreciation of the organizational thinking and management processes of political parties. Advocates of the relationship theory, for example, Gronroos (2004), have argued that there is an end of an era for transactional exchange given its limitations in a number of fields in marketing, including the service sector. They further claim a paradigm shift towards long-term relationships underpinned by intangible characteristics of the 'product' as opposed to the goods dominant character of the managerial approach to marketing (Grönroos, 2004). 
According to Webster (1992), the modern view of marketing is an engagement process focusing on forming long-lasting mutually beneficial relationships. This includes relationships within the institution, referred to as internal partnerships - interaction between functional departments and amongst the firm and its staff (Blomqvist, Dahl \& Heager, 1993; Morgan \& Hunt, 1994). The limitations in the managerial approach to marketing, based on which a paradigm shift is proclaimed (Grönroos, 1996; Gummesson, 1987), and the subsequent proposals to adapt and develop frameworks capable of responding to those limitations, such as a shift towards a relational paradigm have also been noted in the political marketing literature (Henneberg, 2004; Lock \& Harris, 1996; Moufahim \& Lim, 2009). In the early years of the critiques and proposals, Hastings (2003) and Bannon (2003), for example, observed that relationship marketing was yet to be fully applied to the management of the parties and campaigns despite the potential benefits. In recent years, the application of relationship marketing (RM) to the management of politics is growing (Dean \& Croft, 2001). In Ghana, political parties, especially the dominant ones.

The National Democratic Party (NDC) and the New Patriotic Party (NPP) have been rocked by serious implosions; resignations, suspensions, defections to other parties and breakaways. In most cases, aggrieved parties who are mostly constituency executives, allege a disconnect between the base and the leadership. Yet, at the macro-level of party political discourse, there is increasing talk of party unity on political platforms in the media. Hence, the need to examine the micro-level interactions between party leadership and the base to put the internal wrangling in perspective. Hence the research question "how do parties manage internal relationships at the constituency level?" Our study makes two significant contributions. First, the study contributes to the growing body of literature on political marketing by exploring the practice of relationship marketing by political parties in a developing country context. The novelty of the study stems from the application of the concept of relationship marketing which has been developed in the field of commerce to politics. Second, this study provides useful lessons for political actors (parties and candidates) as the findings reveal a deep-seated mistrust among party officers and members.

Objective of the Study: This research investigates the practice of political relationship marketing in the two leading parties in Ghana, focusing on micro-interactions at the constituency level. It notes that such studies are visibly missing in the literature on political marketing in Ghana (Hinson \& TweneboahKoduah, 2010; Mensah, 2009). Mensah (2009), for example, notes that political parties and candidates in Ghana disseminate information about their policies, ideologies and campaign messages to the electorates in broadcast and narrowcast forms through the use of signs, sounds and symbols familiar to the voters. Political campaigns in Ghana are often multi-targeted, deploying broadcast and outdoor advertising, direct marketing and personal selling during elections. Whereas these marketing communication formed between parties and voters are heavily featured in the literature that of internal party management is nonexistent.

\section{Literature Review}

Political Marketing: The marriage between the disciplines of marketing and political science gave birth to a theory known as political marketing (Hughes \& Dann, 2012). The object of which is to adapt the concepts and theories of commercial marketing to explain and understand party organizational behavior (Henneberg, 2008; Wring, 1997). According to Henneberg, Scammell and O'Shaughnessy (2009) political marketing despite its popularity in the US and Europe does not lend itself to an easy conceptualization. There are also blurred lines between political marketing, political communication and political management (Henneberg et al., 2009; Henneberg \& O'Shaughnessy 2009). Similarly, Scammell (1999, p.718) observed that political marketing is "developing cross-disciplinary political/marketing/communication perspectives not simply to explain the promotional features of modern politics but as a tool of analysis of party and voter behavior." This has led to the description of political marketing as a virgin territory that is yet to be fully explored and its theoretical boundaries delineated (Johansen, 2016; Lees-Marshment, 2019). However, one certain thing is that political marketing could leverage the success of commercial marketing to positively influence the structure and operations of politics by delivering value to key target markets, i.e. members, voters, sympathizers and financiers while protecting the interest of other stakeholders such as the media and the general public (Hughes \& Dann, 2012). After all, "politics is a business of ideas, and marketing should not consider itself a neutral participant" (Hughes \& Dann, 2012, p.357). Furthermore, scholars of marketing have argued in the past that any Endeavour that is competitive in nature. 
(Whether for profit or not for profit) should be seen as being engaged in marketing (Bagozzi, 1975; Kotler \& Levy, 1969; Kotler \& Zaltman, 1971). Nonetheless the marriage of marketing and politics like any another union is not bereft of arguments, debates, squabbles and criticisms (Henneberg, et al., 2009). One of the major concerns of the critics of political marketing is its overall impact on democracy and democratic practice (Henneberg, et al., 2009; Johansen, 2012). They are those who think that political marketing is to be blamed for the decline in political astuteness (on the part of political leaders), lack of innovation, promotion of trivialities in political communication and deception of electorates among others (Bennett, 1992; Franklin, 1995; Henneberg \& O'Shaughnessy, 2009; O'Shaughnessy. 2001; O'Shaughnessy, 1990; Savigny, 2006). For some, the rise of political marketing is responsible for the inimical developments in the political landscape, such as a decline in party activism and skeptical electorates or politics as a product designed for the media/market (Cappella \& Jamieson, 1997; Franklin 1997; Swanson 1997). The extreme critics think political marketing is debasing democratic practice and not beneficial to the advancement of politics.

In general (Dermody \& Scullion, 2003; Henneberg et al., 2009; Lilleker, 2005; Moloney \& Colmer, 2001). O'Shaughnessy $(1990$, p.6) rebut these criticisms by suggesting that "the answer to the ethical question (regarding, political marketing) depends on the views of democracy we hold." Aside from these criticisms by political scientist which is largely focused on the ethical dimension of political marketing, marketing theorist has equally raised concerns about the weaknesses in the political marketing theory (Henneberg, 2004). For example, scholars from the European region have been consistent with their views that politics should be considered as a service product (Baines \& Egan, 2001; Brennan et al., 2003; Harrop 1990; Henneberg 1997; Scammell 1999; O'Shaughnessy 2001) yet this has not been reflected in the literature which has been dominated by the managerial school of thought where the emphasis is on the marketing mix model (Johansen, 2012). Henneberg et al. (2009) observe that just as mainstream marketing is replete with varied conceptualizations of its dimensions and approaches, political marketing equally has different conceptualizations of its approaches. Examples of such conceptualizations include; Lees-Marshment's (2001) three typologies of product orientation, sales orientation and market orientation.

Dean and Croft (2001) marketing is the exchange, marketing is different and politics is different; Henneberg et al. (2009) selling oriented political marketing management, instrumentally oriented political marketing management and relational oriented marketing management. We will briefly expound on the classification of Henneberg et al. (2009) because of its relationship with our study. The selling orientation is akin to the orthodox value-laden and ideology-oriented politics (Henneberg, 2002; Kavanagh, 1995). With this orientation political offerings are often created based on the dominant core value system of the party (Henneberg et al., 2009). Contemporary examples of selling-oriented parties would be single-issue parties such as the 'Brexit Party' in the UK, Green Parties which use specific marketing tools to promote their cause. Marketing tools such as posters, mass communication through electronic media (O'Shaughnessy, 2005). According to Henneberg et al. (2009), the instrumental orientation reflects the current dominant logic in political marketing research. It describes political parties' use of sophisticated marketing tools to persuade the electorates to consider choosing their products (policy promises), which are sometimes customized to satisfy a particular segment of voters (Henneberg et al., 2009). This is similar to what Lees-Marshment (2001) described as market(ing) orientation.

Where the focus of the marketing efforts of parties is the voter - the needs and preferences are incorporated into the design of the parties' offerings (Henneberg, 2006). This orientation requires an effective blend of varied marketing techniques that respond to marketing insight gathered from the electorate through opinion polls and surveys (Henneberg et al., 2009; Johansen, 2005; Wring, 2005). The relational approach to political marketing or what Henneberg and O'Shaughnessy (2009) called 'political relationship marketing' is anchored on forming and maintaining long-term relationships with the electorates. Prior to the work of Henneberg and O'Shaughnessy (2009), there had been calls for the application of relationship marketing to politics (Bannon, 2005; Newman, 2002). The relational approach advocates for a ship away from one-off transactional exchange to a focus on lifetime value achieved through continued interactions, networking and co-creation of policy promises (Johansen, 2005; Laczniak \& Murphy, 2006). According to Ormrod (2020), an exchange of value in the political sphere is not a oneoff event but a three-tier process. The exchange process starts with the candidate making promises to the electorates, which can only be redeemed if voted for and having leverage on the legislature (Henneberg \& Ormrod, 2013; Ormrod, 2017, 2020). 
All these three episodes of interactions are influenced by the activities of public affairs professionals such as lobbyists (Bitoni \& Harris, 2017; Brown, 2016; De Bruycker, 2019). Henneberg et al. (2009, p.172) conclude that "relational political marketing management is based on a comprehensive and 'permanent' (i.e. continuously ongoing) portfolio of marketing activities, including policy development, communication, implementation, and long-term relationship and stakeholder management." They further pointed out that among the three marketing models discussed the relational political marketing approach appears more compatible with the concept of democracy. This is because political relationship marketing insists on the formation of relationships with voters and getting to know their needs and preferences instead of relying on polls and surveys (Henneberg \& O'Shaughness, 2009; Johansen, 2005).

Political Relationship Marketing: Relationship marketing in the context of service, in which politics is part, is known to have been introduced first by Berry (1983), defined as attracting, maintaining and enhancing customer relationships. To Gronroos (1994), the marketing mix paradigm that underpins managerial marketing, and which has dominated marketing thought, practice and research in almost the last four decades is fast losing its position to the emerging relationship marketing paradigm. Similarly, political marketing which used to be "transaction-oriented" (O'Shaughnessy, 1990; O'Shaughnessy 2005) is giving way to the relational approach to political marketing (Elder \& Lees-Marshment, 2019), which scholars believe would better explain the theory of political marketing (Scammell 1999; Bannon 2003; Dean \& Croft 2001). It has been argued that the relational marketing approach or what Henneberg and O'Shaughnessy (2009) termed as political relationship marketing is the ideal of all the political marketing models that would suit the deliberative nature of democracy (Henneberg et al., 2009; Dean \& Croft, 2001; Newman 1999; O’Shaughnessy, 1990).

It has also been noted in the political marketing literature that political relationship marketing could create the platform for useful dialogue between political actors (candidates and parties) the electorates (Bannon, 2005; Johansen, 2005; Henneberg \& O'Shaughnessy 2009). Just as in commerce, political actors and the electorates believe that political exchanges should not be seen as a one-off exchange transaction (voting for a candidate in an election) but a continuous social engagement around which their lives evolve (Elder \& Lees-Marshment, 2019; Sniderman et al., 1993). Besides, the opportunity to cultivate and nature long-term relationships based on trust and commitment (Morgan \& Hunt 1994) would be an irresistible offer for politicians (Henneberg \& O'Shaughnessy, 2009). Although the relationship marketing theory emerged in the early 80s, it was not until the early 2000s that researchers contemplated its application to politics (Henneberg \& O'Shaughnessy, 2009). Scammell (1999) was emphatic when she claimed that there was barely any literature on political relationship marketing. Among the pioneering works on the relational approach to political marketing is that of Dean and Croft (2001) which adapted the six market model of Christopher et al. (1991) to arena politics.

While this study highlighted some of the intricacies associated with the political exchange process and the possibility of relationships, it failed to explain the essence of these relationships to politics (Henneberg \& O'Shaughnessy, 2009). According to Bannon (2008) relational approach to political marketing though not new in marketing because its core principles are akin to direct marketing, its suitability and applicability in the sphere of politics remain an unchartered territory that requires further probe. Other scholars such as Henneberg and O'Shaughnessy (2009); Bannon (2003) have bemoaned the lack of interest in the relational approach to political marketing by scholars in the field, despite the potential positive impact political relationship marketing could have on political actors and democracy in general. For example, Henneberg and O'Shaughnessy (2009) posit that political relationship marketing could foster continuous interactivity between political actors and voters which would make voters active participants of the political exchange process instead of the current situation where they (voters) sometimes feel alienated. One of the shortfalls of the current approaches to political marketing is voter manipulation and lack of trust for the political class by voters.

This could be cured by the relational approach because the key underlying principles of relationship political marketing are trust and keeping promises which have proven to be daunting tasks for many politicians (Bannon, 2008; Henneberg \& O'Shaughnessy, 2009). One key criticism of political relationship marketing is the lack of conceptual development. For instance, the dimensions and constructs that are needed to further explain the concept and also facilitate empirical studies are still lacking (Henneberg \& O'Shaughnessy, 2009; Henneberg et al., 2009). To operationalize political relationship marketing, its conceptual development has to be extended beyond the "cosmetic and superficial" (Henneberg, et al., 2009, p.170) acts. Despite these shortfalls, a critical examination of the current practice of political 
marketing would reveal some traces of political relationship marketing. For example, the 2008 campaign of Barrack Obama adopted marketing strategies that did not entice electorates to their online platforms but sought to convert them to loyal supporters (Johansen, 2016). This validates the claim of Henneberg and O'Shaughnessy (2009) that political parties could benefit more if they were to integrate IT into political relationship marketing, as this would not only increase party membership but could foster participatory decision making.

\section{Methodology}

This is a qualitative study (Creswell, 2007) aimed at exploring how internal relationships are managed in the case constituencies of political parties in Ghana. This study is phenomenological in nature because it sought to explore respondents' "perceptions, feelings and lived experiences" (Guest, Namey and Macqueen, 2012, p.12) about internal party relationships. A combined data source of in-depth interviews of constituency executives and party constitution was used (Lilleker, 2003). Interviews were adopted because of their ability to provide insightful data that reflect participants' personal thoughts, feelings worldview (Guest, Namey, Taylor, Eley \& McKenna, 2017). The two parties' activities in the constituencies are guided by their constitutions. In the two parties, there are no additional documents such as constituency meeting guide, training guide, outreach guide, etc that offer any "to do" framework besides the broad brush party constitution, which only offers policy level statements of what is expected. This was noted by the party executives interviewed, and our frantic search online also failed to return any such documents. For the in-depth interview a sample of 24 respondents (Creswell, 1998; Morse, 1994), comprising three party executives from each of the eight case constituencies were selected. In arriving at the sample, the party constituency population was categorized.

Into urban stronghold constituencies, sub-urban stronghold constituencies, urban orphan constituencies and sub-urban orphan constituencies. As an operational definition in this study, a constituency is considered a stronghold when it has been won three consecutive times by the same party in elections. This definition reflects that of the extant literature where a constituency is regarded as a stronghold of a particular party if the party has won all elections in a given period of time in the constituency (See Keefer \& Khemani, 2009). This study defines an orphan constituency as one that has not been won by one party in three electoral cycles. The data collection for the study was done between January and March 2016. Data was collected through interviews with the help of an interview guide (Guest, Bunce \& Johnson, 2006). The interview guide was semi-structured, this allowed for clarification to be sought when necessary. The interviews were conducted in English and later transcribed into text (McLellan, MacQueen, \& Niedig 2003). The two authors each went through the transcribed text against the voice recordings to ensure accuracy (Guest et al., 2006). Thematic analysis technique was used to identify attributes for categorization (Guest, et al., 2012, Guest, et al., 2006). Thematic analysis is by far the most effective and popular analytical tool used in text-based data analysis because of its ability to flesh out the intricate details hidden in the data (Guest et al., 2012).

Table 1: Coding Framework Relationship
Categories
Attributes
(1) Interactivity
(2) Networking
(3) Functional relationship
(4) Internal message sale
(5) Integrated communication
Organizational Culture
(6) Reduced conflict
(7) Reduced crosscheck
(8) Team work
(9) Probity
(10) Equity
(11) Reliability
(12) Relationship importance
(1) Cooperation
(2) Leadership support
(3) Trust 


\section{Organizational Climate}
(4) Fairness
(5) Friendliness
(6) Reduced conflict
(7) Performance standard
(8) Commitment

Source: Author's construct.

\section{Findings and Discussion}

As noted in the methodology above, in-depth interviews were conducted. These interviews were recorded on tape and later transcribed into text. After synthesizing and analyzing the data the following themes emerged; interactivity, networking, internal partnership, trust and commitment. These shall be explained in the sections that follow, under subheadings interactivity and networking, internal partnerships and trust and commitment.

Profile of Participants: The demographic profile of the participants as illustrated in table 2 indicates that the majority of the respondents were male precisely 83.33 percent and 16.67 percent were female. The ages of the participants ranged between 28 to 55 years with a mean age of 35.9 years. This is an indication that the youth is taking a special interest in politics at the grassroots level. In terms of education, the majority (66.67 \%) of the participants were degree holders, 12.5 percent had education up to the postgraduate level and 20.83 percent were diploma holders. When an inquiry was made about participants' political experience it emerged that their experiences ranged between 5 to 20 years with a mean experience of 10.8 years.

Table 2: Sample Characteristics

\begin{tabular}{lr}
\hline \multicolumn{1}{c}{$\mathbf{N}=\mathbf{2 4}$} \\
\hline Gender & $20(83.33 \%)$ \\
Male & $4(16.67 \%)$ \\
Fge & \\
$\quad$ Range & $28-55 \mathrm{yrs}$ \\
$\quad$ Mean & 35.9 \\
Education & \\
$\quad$ Diploma & $5(20.83 \%)$ \\
Degree & $16(66.67 \%)$ \\
Postgraduate & $3(12.5 \%)$ \\
Political Experience & $5-20 \mathrm{yrs}$ \\
Range & 10.8 \\
Mean &
\end{tabular}

Source: Authors' construct.

\section{Attributes of Political Relationship Marketing in Party Constituencies}

Interactivity and Networking: Is there evidence of interactivity and networking in the case constituencies? From the data table above, attributes 1-3; interactivity, networking, functional relationship, were observed by party executives as fundamental to their work. The attributes were also noted in the parties' constitutions. These attributes were measured by frequency of meetings, unhindered information flow amongst functional executives using varied forms of communication channels, as well the existence of inter-committee working groups. To these questions, the following are some of the responses: Sometimes we meet twice a month. We don't really have scheduled time for meetings but our party branches do hold weekly meetings to discuss party matters. We often make efforts to attend these meetings to interact with our officers and learn at first hand some of the concerns of the party officers and members at that level. We often communicate with the regional office, but let me add that most of the time it is the regional office that initiates our interaction with them. Besides meetings, we also do communicate through telephone, fax and sometimes email, we do communicate through social media, particularly using the WhatsApp platform to share information and discuss party matters.

Yes, we work together the research officer works closely with the communications officers. The use of technology seems to enhance the level of interactivity and networking, ensuring that party discussions 
are not limited to physical meeting days only. Executives in the case constituencies note the increasing use of social media platforms and other ICT channels such as WhatsApp, Facebook and Emails as platforms that greatly facilitate their meetings. This finding reinforces the assertion of Henneberg and O'Shaughnessy (2009) that political relationship marketing would be better enhanced if it is integrated with IT. These platforms are not only used within group members but also cross-functional areas: oh yes, we communicate through WhatsApp often; for example, we have groups like constituency secretaries group platforms, chairmen platform, organizers group platform, and so on. At the regional level too there are such group platforms that are mainly used to disseminate information. Analyses of the two-party constitutions also show evidence of the three attributes. For example, article 6, section 1 of the NPP constitution provides that each constituency shall have a constituency executive committee, which shall consist of all the functional areas including: finance, organization, research, communication, and the coordinators of the various demographic groups.

It demands, in section 8 that the constituency executive committee: shall meet at least once every, month and shall present quarterly reports on the operations and activities of the party in the constituency to the regional executive committee. Whereas a similar arrangement of interactivity and networking amongst party functionaries is observed in the NDC constitution, the constitution is however silent on the frequency of such interactions. For example, article 11 of the constitution observed that the party is also organized at the branch, and article 13 highlights the mandate of the branch meetings. Article 14 and 24 demand that party branch executives must reflect all functional areas including finance, organization, research communication and all coordinators of various interests' groups. The dialogical, interactive and functional relationship to internal constituency management, as observed in the quotes above, especially in the case of NPP characterize the relational approach to political marketing, as noted in the literature on political relationship marketing (Banon, 2008; Henneberg, et al., 2009; Henneberg \& O'Shaughnessy, 2009). This means the case constituencies have relational characteristics. However, it could also be argued that these attributes are characteristic of political organizations given their nature, and so do not immediately suggest that the constituencies are relationship-oriented.

Internal Partnership: Another relational attribute gleaned for data was internal partnerships. Literature (Christopher et al., 1991; Gummesson, 1991) suggests that in organizations where there are internal partnerships functionaries see each other as customers, assess their needs and sell to them using an integrated communication approach. The internal partnership also means that functionaries work together in a way that could reduce needless crosschecking, and reduce conflict situations as well as empowerment of frontline staff. In a question, are you allowed to take decisions on party matters without reference to your superiors? The following answers were typical of almost all the eight case constituencies: our work involves going into the hinterlands, places where you cannot even have access to telephone services or the internet. If you are confronted with a problem in such an environment you can only act on your own because you can't defer the issue and you are also out of coverage area. You have to deal with the issue and then later brief your colleagues and superiors. Our work requires us to deal with issues on the spot without having the benefit of consultation. For example, you go to the remote villages to interact with the party members and you are presented with a problem, you have no choice but to try and resolve it there and then.

In the case of constituencies these attributes, though evident in the parties, are seeds of conflict as opposed to reducing conflict. This is because respondents have noted that constituency party executives are not given training, and there is no 'standard operational procedure (SOP)' based on which their activities are guided. It is also noted that educational qualification is not needed in most of the contests for party executive positions. So not crosschecking with other leadership could present a situation of 'organizational discord,' with the potential of increasing conflict situations on party position to issues since individuals are, by default, expected to act based on their volitions, judgment, and inherent knowhow. In addition, when party respondents were asked how conflicts arise in the daily management of the constituency, the majority referred to party primaries as a major source: Unfortunately, in recent years our disagreements have escalated and we wash our dirty linen in public because of perceived factionalism. During our party primaries, for instance, you find executives supporting one candidate over the other and because of these preferences we throw mud at each other forgetting that we are members of the same family. Some of these conflicts and tensions are sometimes due to personal grudges between party officers and/or members. 
Mostly these conflicts arise during our primaries. From the interview transcripts, there was no evidence of party functionaries seeing themselves as customers to appeal to or be persuaded by in case of dissent or disagreements on party positions. Divergent views to party hierarchy positions are considered insubordination, which could merit disciplinary action. A similar situation is evident in the constitutions of the two parties, where failure to uphold publicly party policies is considered misconduct (NPP constitution, Article 4 section 7; NDC constitution article 39 and 40). From the constitutions of the two parties, attempts to reduce conflict situations were also through party disciplinary process, where they specify punitive measures for members who do not follow party rules and regulations (NPP constitution, Article 4 section 7; NDC constitution article 39 and 40). The inter-functional approach to committee formation is another step to encourage teamwork; reduce conflicts and ensure crosschecking is limited to the minimum.

Trust and Commitment: Trust and commitment were yet another theme that emerged after synthesizing the data. This finding resonates with views expressed in the political marketing literature which suggest that the key underlying principles of the relational approach to political marketing are trust and keeping promises (Bannon, 2008; Dean \& Croft, 2001; Henneberg \& O'Shaughnessy, 2009;). According to the relationship marketing text, trust and commitment form part of the underpinnings of relationship-oriented organizations. As discussed in the review of the literature, both trust and commitment are input and output variables. That is, a relationship may begin based on trust and commitment to the terms of the relationship. At the same time, a relationship may begin with individuals doubting their commitments. In the case of constituencies, the party executives did not find these ingredients in internal party relationships. For example, when respondents were asked about the kind of conflict situation.

They experienced in the daily running of the constituency, majority referred to lack of transparency in reward systems, factionalism and suspicions amongst executives: some time ago this party used to be strongly united but now because of this perceived action in our party, there are a lot of suspicions and tensions. We have allowed a few people's interests to tear the party apart. This person says I belong to this camp and another says I belong to this camp. This kind of division is causing our downfall. The only reward we often receive for solving party issues on our own is verbal praise, meanwhile, sometimes we have to use our own resources to solve these problems. Oh, such opportunities (personal development) exist, but you see we at the lower level here hardly benefit from this policy; it is only those at the national office who enjoy these opportunities. They can go for further studies paid for by the party and some officers to get the opportunity to attend refresher courses often organized by NGOs.

Theoretical and Practical Implication: The findings of the study in our view make a modest yet significant contribution to the conceptualization of political relationship marketing. First, the concept of relationship marketing has been developed in the field of commerce but the same cannot be said about its application in politics particularly in the African context. In addition, the current literature on political relationship marketing is dominated by conceptual papers with very limited empirical studies hence studies like this one bring different perspectives to the development of the theory specifically in the area of construct development. Furthermore, this study provides useful lessons for political actors (parties and candidates) as the findings reveal a deep-seated mistrust among party officers and members. Political parties and candidates could find these findings useful in their quest to adopt political relationship marketing, as trust and keeping of promises are at the heart of the theory (Bannon, 2008; Dean, \& Croft, 2001; Henneberg \& O’Shaughnessy, 2009).

\section{Conclusion and Recommendations}

This study sought to explore the practice of political relationship marketing in political parties at the local level. After analyzing the data, it emerged that some form of political relationship marketing is being practiced. Evidently, the most prevailing attributes of political relationship marketing in the eight case constituencies are interactivity and networking. These attributes are fully practiced and are widely sanctioned in the constitutions of the case parties. Beyond that, the two political parties show a profound deficit in internal partnership and trust and commitment attributes to the extent that the majority of their activities are seeds for conflicts. For example, party executives are aware of personal development opportunities but note that they only exist at party headquarters. Currently, there is a lack of a clear strategic plan by the parties on the implementation of relationship marketing. It is recommended that 
political parties should design deliberate strategies to promote trust and partnership which are vital to internal relationship management.

Limitations and Suggestions Future Research: Characteristic of any research work, this study has some limitations which need to be noted when interpreting the findings. First, the use of a semistructured interview guide did not quite allow for open discussion of issues by participants or perhaps they were just being cautious. Questions that were expected to elicit open-ended responses got very brief answers. It will therefore be a useful academic exercise to further explore the subject matter by using different qualitative data collection approaches such as focus group discussion. Furthermore, the themes that emerged from the findings could be developed into constructs to measure political relationship marketing in a quantitative study.

\section{References}

Bagozzi, R. P. (1975). Marketing as exchange. Journal of Marketing, 4(39), 32-39.

Baines, P. R. \& Egan, J. (2001). Marketing and political campaigning: mutually exclusive or exclusively mutual? Qualitative Market Research: An International Journal, 4(1), 25-34.

Bannon, D. P. (2005). Relationship marketing and the political process. Political Marketing Conference, Middlesex University.

Bannon, D. P. (September 2003). Relationship marketing and the political process Paper presented at the Political Marketing Conference, London.

Bennet, R. (1992). The customer-driven competitive edge. Bank Marketing, 24(5), 50-52.

Berry, L. L. (1983). Relationship marketing in Berry, L. L., Shostack, G. L. and Upah, G. D. (Eds), Emerging Perspectives on Services Marketing (pp.25-28). American Marketing Association.

Bitoni, A. \& Harris, P. (2017). Lobbying in Europe: Public affairs and the lobbying industry in 28 EU countries. Palgrave MacMillan.

Blomqvist, R., Dahl, J. \& Haeger, T. (1993). Relations marknadsforing: Strategic method for service kon kurren (relationship marketing: strategy and methods for service competition). IHM Forlag, Goteborg.

Bowler, S. \& Farrell, D. M. eds. (1992). Electoral strategies and political marketing. Macmillan Press.

Brown, R. (2016). Firm-level political capabilities and subsequent financial performance. Journal of Public Affairs, 16, 303- 313.

Brown, M. B. \& K. Coates. (1996). The Blair revelation: Deliverance for whom? Spokesman.

Cappella, J. N. \& Jamieson, K. (1997). Spiral of cynicism. The press and the public good. Oxford University Press.

Christopher, M. G., Payne, A. F. T. \& Ballantyne, D. (1991). Relationship marketing. Heinemann.

Creswell, J. W. (2007). Qualitative inquiry and research design: Choosing among five approaches, (2nd ed.). Sage.

Creswell, J. (1998). Qualitative inquiry and research design: Choosing among five traditions. Sage.

Dean, D. \& Croft, R. (2001). Friends and relations: long-term approaches to political campaigning. European Journal of Marketing, 35(11/12), 1197-1217.

Dermody, J. \& Scullion, R. (2003). Exploring the consequences of negative advertising in liberal democracy. Journal of Political Marketing, 1(2), 77-100.

De Bruycker, I. (2019). Lobbying: An art and a science - five golden rules for an evidence-based lobbying strategy. Journal of Public Affairs, 19, 1-4. https://doi.org/10.1002/pa.1949

Elder, E. \& Lees-Marshment, J. (2019). Relational political marketing communication. In Political Marketing (pp. 183-210). Routledge.

Franklin, B. (1995). Packaging Politics. Arnold.

Franklin, B. (1997). Newzak and News Media. Arnold.

Grönroos, C. (2004). The relationship marketing process: communication, interaction, dialogue, value. Journal of Business \& Industrial Marketing, 1(2), 99-113. doi.org/10.1108/08858620410523981

Grönroos, C. (1996). Relationship marketing: Strategic and tactical implications. Management Decision, 34(3), 5-14. doi.org/10.1108/00251749610113613

Gronroos, C. (1994). From marketing mix to relationship marketing: towards a paradigm shift in marketing. Management Decisions, 32(2), 4-20. doi.org/10.1016/S1320-1646 (94)70275-6

Guest, G., Namey, E., Taylor, J., Eley, N. \& McKenna, K. (2017). Comparing focus groups and individual interviews: findings from a randomized study. International Journal of Social Research Methodology, 20(6), 693-708. DOI: 10.1080/13645579.2017.1281601 
Guest, G., MacQueen, K. M. \& Namey, E. E. (2012). Introduction to applied thematic analysis. Applied thematic analysis, 3(20).

Guest, G., Bunce, A. \& Johnson, L. (2006). How many interviews are enough? An experiment with data saturation and variability. Field methods, 18(1), 59-82.

Gummesson, E. (1991). Marketing-orientation revisited: The crucial role of the part-time marketer. European Journal of Marketing, 25(2), 60-75. doi.org/10.1108/03090569110139166

Gummesson, E. (1987). The new marketing-developing long-term interactive relationships. Long Range Planning, 20(4), 10-20. doi.org/10.1016/0024-6301 (87)90151-8

Harker, M. J. (1999). Relationship Marketing Defined? An examination of current relationship marketing definitions. Marketing Intelligence and Planning, $17 \quad$ (1), 13-20. doi.org/10.1108/02634509910253768

Harrop, M. (1990). Political marketing. Parliamentary Affairs, (43), 277-91.

Hastings, G. (2003). Relational paradigms in social marketing. Journal of Macro-marketing, 23(1), 6-15. doi.org/10.1177/0276146703023001006

Henneberg, S. C. \& Ormrod, R. (2013). The triadic interaction model of political marketing exchange. Marketing Theory, 13, 87-103. https://doi.org/10.1177/1470593112467269

Henneberg, S. C. \& O'Shaughnessy, N. J. (2009). Political relationship marketing: Some macro/micro thoughts. Journal of Marketing Management, 25(1-2), 5-29.

Henneberg, S. C., Scammell, M. \& O'Shaughnessy, N. J. (2009). Political marketing management and theories of democracy. Marketing Theory, 9(2), 165-188.

Henneberg, S. C. (2008). An epistemological perspective on research in political marketing. Journal of political marketing, 7(2), 151-182.

Henneberg, S. C. (2006). Leading or following? A theoretical analysis of political marketing postures. Journal of Political Marketing, 5(3), 29-46.

Henneberg, S. C. (2004). The Views of an Advocatus Dei: Political Marketing and its Critics." Journal of Public Affairs, 4(3), 225-243. doi.org/10.1002/pa.187

Henneberg, S. C. (2002). Understanding political marketing. The idea of political marketing, 93-170.

Henneberg, S. C. M. (1997). Voting behavior as a special case of consumer behavior. Judge Institute of Management Studies, University of Cambridge.

Hinson, R. \& Tweneboah-Koduah, E. Y. (2010). Political marketing strategies in Africa: expert opinions of recent political elections in Ghana. Journal of African Business, 11(2), 201-218. doi.org/10.1080/15228916.2010.508999

Hughes, A. \& Dann, S. (2012). Political marketing redefined: Exploring the consequences of stakeholders on the marketing mix and political consumption. ACR Asia-Pacific Advances.

Johansen, H. P. (2012, 2016). Relational political marketing in party-centered democracies: Because we deserve it. Routledge.

Johansen, H. P. M. (2005). Political marketing: more than persuasive techniques, an organizational perspective. Journal of Political Marketing, 4(4), 85-105.

Kavanagh, D. (1995). Election Campaigning: The New Marketing of Politics. Blackwell.

Keefer, P. \& Khemani, S. (2009). When do legislators pass on pork? The role of political parties in determining legislator effort. American Political Science Review, 103(1), 99-112. https://doi.org/10.1017/S0003055409090054

Kotler, P. \& Keller, K. L. (2012). Marketing management, 14th Edition. Prentice-Hall, One-Lake Street.

Kotler, P. \& Zaltman, G. (1971). Social marketing: An approach to planned social change. Journal of Marketing, 35(3), 3-12.

Kotler, P. \& Levy, S. J. (1969). Broadening the concept of marketing, Journal of Marketing, 3(33), 10-15.

Laczniak, G. R. \& Murphy, P. E. (2006). Normative perspectives for ethical and socially responsible marketing. Journal of Macro marketing, 26(2), 154-177.

Lees-Marshment, J. (2019). Marketing scholars and political marketing: the pragmatic and principled reasons for why marketing academics should research the use of marketing in the Political Arena. Customer Needs and Solutions, 6(3-4), 41-48.

Lees-Marshment, J. S. (2009). Marketing after the election: The potential and limitations of maintaining a market orientation in government. Canadian Journal of Communication, 34(2), 205-227.

Lees-Marshment, J. (2004). Mis-marketing the conservatives: The limitations of style over substance. Political Quarterly, 75(4), 392-397. doi.org/10.1111/j.1467-923X.2004.00641.x

Lees-Marshment, J. (2001). Political marketing and British political parties. Manchester University Press.

Lilleker, D. \& Jackson, N. (2013). Political campaigning, elections and the Internet: Comparing the US, UK, France and Germany. Routledge. 
Lilleker, D. G. (2005). The cause of an emerging democratic deficit in Britain? Journal of Nonprofit \& Public Sector Marketing, 14(1/2), 5-26.

Lilleker, D. G. (2003). Interviewing the political elite: Navigating a potential minefield. Politics, 23(3), 207214.

Lock, A. \& Harris, P. (1996). Political marketing-vive la difference! European Journal of Marketing, 30(10/11), 14-24. doi.org/10.1108/03090569610149764

Mauser, G. A. (1983). Political marketing: An approach to campaign strategy. Praeger.

McLellan, E., MacQueen, K. M. \& Niedig, J. (2003). Beyond the qualitative interview: Data preparation and transcription. Field Methods, 15(1), 63-84.

Mensah, K. (2009). Symbolically speaking: The use of semiotics in marketing politics in Ghana. Identity, Culture and Politics: An Afro-Asian Dialogue, 10(1), 75-89.

Mensah, K. (2017). Political marketing and management: A new architecture. In Political Marketing and Management in Ghana (pp. 1-16). Palgrave Macmillan, Cham.

Moloney, K. \& Colmer, R. (2001). Does political PR enhance or trivialize democracy? Journal of Marketing Management, 17, 957-68.

Morgan, R. M. \& Hunt, S. D. (1994). The commitment- trust theory of relationship marketing. Journal of Marketing, 58(3), 20-38. DOI: $10.2307 / 1252308$

Morse, J. (1994). Designing funded qualitative research. In N. Denzin and Y. Lincoln (1994) Handbook for qualitative research, (ed., pp.220-35). Sage.

Moufahim, M. \& Lim, M. (2009). Towards a critical political marketing agenda? Journal of Marketing Management, 25(7-8), 763-776. doi.org/10.1362/026725709X471613

Newman, B. (2002). The role of marketing in politics. Journal of Political Marketing, 1(1), 1-5.

Newman, B. I. (1999). The Mass Marketing of Politics. Sage.

Newman, B. (1994). The Marketing of the President. Political Marketing as Campaign Strategy. Sage.

Nickerson, D. W. \& Rogers, T. (2014). Political campaigns and big data. Journal of Economic Perspectives, 28(2), 51-74. DOI: $10.1257 /$ jep.28.2.51

Ormrod, R. P. (2020). Political exchanges of value and the stakeholder concept: Implications for public affairs. Journal of Public Affairs, e2084.

Ormrod, R. P. (2017). Stakeholders in the political marketing context. Journal of Public Affairs, 17, e1671. https://doi.org/10.1002/pa.1671

O'Shaughnessy, N. J. (2005). Politics and propaganda: Weapons of mass seduction. University of Manchester Press.

O'Shaughnessy, N. (2001). The marketing of political marketing. European Journal of Marketing, 35(9/10), 1047-57.

O'Shaughnessy, N. (1996). Social propaganda and social marketing: A critical difference? European Journal of Marketing, 30(10/11), 54-67. doi.org/10.1108/03090569610149791

O'Shaughnessy, N. J. (1990). The phenomenon of political marketing. Springer.

O’Shaughnessy, N. \& Henneberg, S. (2002). The idea of political marketing (Eds.), Praeger.

Reeves, P. (15th-17th September 2009). Political parties and political marketing 'strategies'. Paper Submitted to British Academy of Management Conference 2009, Brighton UK.

Savigny, H. (2006). Political marketing and the 2005 election: what's ideology got to do with it? D. G. Lilleker, N. A. Jackson and Scullion, R. (2006). The marketing of political parties. Manchester University Press.

Scammell, M. (1999). Political marketing: lessons for political science. Political Studies, 47(4), 718-739. doi.org/10.1111/1467-9248.00228

Scammell, M. (1995). Designer Politics: How elections are won. Palgrave Macmillan UK.

Sniderman, P. M., Brody, R. A. \& Tetlock, P. E. (1993). Reasoning and Choice: Explorations in Political Psychology, Cambridge University Press.

Swanson, D. (1997). The political-media complex at 50. American Behavioural Scientist, 40(8), 1264-82.

Tweneboah-Koduah, Y. E., Akotia, M., Akotia, C. S. \& Hinson, R. (2010). Political party brand and consumer choice in Ghana. Journal of Management Policy and Practice, 11(5), 79-88.

Webster, Jr, F. E. (1992). The Changing Role of Marketing in the Corporations. Journal of Marketing, 56(4), 1-17. DOI: $10.2307 / 1251983$

Wring, D. (1997). Reconciling marketing with political science: theories of political marketing. Journal of Marketing Management, 13, 651-66. 